\title{
The Need for Professional Development of Educators: A Key to Improving the Culture of Teaching and Learning
}

\author{
J.G. Kheswa N.S. \\ Department of Psychology, University of Fort Hare, Private Bag X 1314, Alice, 5700 South Africa. \\ Email:jkheswa@ufh.ac.za \\ Sandlana \\ Department of Psychology, University of Fort Hare, Private Bag X 1314, Alice, 5700 South Africa. \\ Email: nsandlana@ufh.ac.za \\ S. J. Kwatubana \\ School of Educational Sciences North- West University (Vaal Campus), \\ P.O Box 1174, Vanderbijpark, 1900, South Africa \\ Email: Sipho.Kwatubana@nwu.ac.za
}

\section{Doi:10.5901/mjss.2014.v5n20p2864}

\section{Abstract}

Professional development of educators is important in advancing educational practices. The resultant collaboration between the district and school (i.e. principals and educators) serve as a foundation for skills acquisition, assessment and learner's performance. Grounded in motivation theory and various models advocating professional development, this article proposes strategies on how educators can enhance their teaching methods for learners' academic performance, since the barriers to learning are enormous(e.g scarcity of resources, poverty, overcrowding ). The findings of this paper reveal that professional development can contribute towards assessment, identification and counselling of learners based on collaboration between the district and educators, including the principals.

Keywords: Professional development, educators, academic performance, teaching styles,

\section{Introduction}

Professional development of educators must be a prerequisite for any education system. It updates educators about their general education and subject knowledge. Furthermore, educators who undergo professional development workshops, gain insight which helps them to understand themselves, and expand their teaching skills and learning processes (Donald, Lazarus \& Lolwana, 2006). Niemann (2008) advocates that professional development should be in line with the South African Skills Development Act of 1998 and align with broader national norms, the personal career development plan of individuals and the strategic organisational needs of the schools. Professional development refers to any activities aimed at improving the quality of teaching, by means of on-going training and support, and allows learning to be integrated in a meaningful, concrete way that addresses specific challenges educators have in their own classrooms (Lessing \& de Witt, 2007). It embodies high quality and relevant teacher- education programmes which respond to the diverse needs of learners and educators in order to promote competence and collaboration among all stakeholders (parents, learners, district and educators) (Scheerens, 2010). Mullen (2000) asserts that collaboration is important as it encourages teamwork and creative partnership between educators to identify mutually defined barriers and needs, and ways to meet such needs and when professional development has collaboration. When professional development is continuous, educators become intrinsically motivated and tend to bring their prior knowledge and experience, which, in turn, contributes to their competence, confidence and commitment to teaching and learning. Because of their involvement in such workshops, they are taught how to specifically assess their own practices, and apply different teaching and learning methods that enhance cognitive stimulation of learners (Bredeson, 2003).

Professional development deepens educators' knowledge of the learning areas, sharpen their skills in the classroom and generate new knowledge. Furthermore, it addresses identified gaps in learner achievement, increases the 
ability of the educator to monitor the academic progress of the learner, and It is up- to- date with both the learning content and education in general (Joyce \& Showers, 2003; Richter, Kunter, Klusmann, Lüdtke \& Baumert, 2010). Through professional development, educators get an opportunity to enhance their professional competence, self-regulatory skills and beliefs about teaching and learning (Lumpe, Czerniak, Haney \& Beltyukova, 2012). Furthermore, Rebore (2014) mentions that in in-service training of educators, conflict tolerance is being emphasized for growth and development of the school rather than creating animosity against fellow colleagues. Conflict tolerance refers to the degree to which educators and principals are encouraged to express their criticism openly and be provided with feedback that is going to contribute to their approach towards teaching and handling learners and parents from diverse backgrounds.

As stipulated in the South African School Act, by being professionally developed, educators keep abreast of change and educational trends and behave in a way that promotes the dignity of the profession (Clarke, 2007). In a research conducted by Harwell (2003) among educators who participated in a quantitative study, it was revealed that professional development equipped them better in the areas such as subject-mastery, assessment and classroom management, as compared to educators who do not attend professional development workshops. In a South African study comprised of 95 participants (89.5\% female educators and only $10.5 \%$ male educators) in Shoshanguve Township near Pretoria, Lessing and de Witt (2007) found that majority indicated that the professional development workshops contributed to the improvement of teaching habits and on support for learners with learning difficulties.

\section{Conceptual Framework}

Drawing from motivation systems theory, competence of educators could be a combination of a person's motivation, skills and environment (Lumpe et al., 2012). However, Richter et al., (2012) highlight that there could be educators who do not invest in professional development. For example, educators who have been in teaching for more than thirty years and beyond may not find the relevance of attending the in-service training because they approach retirement and chances of being promoted are minimal. One theory that explains a lack of motivation from such educators is called socio-emotional selectivity theory which asserts that older educators tend to pursue less new information when they become aware of their limited time perspective. To keep educators active, mentoring is important. Mentoring is described as practitionercentred, experiential and research oriented, reflective and empowering. Through mentoring, educators may join forces and learn from one another. Various studies around the world indicate that through collaboration, educators collect, analyse and interpret data systematically and carefully (Huberman, 1996). In agreement with Mullen is Sethosa (2001) who found that educators may bring change on how they teach and acquire skills to impart knowledge to their learners rather than being dominant during teaching, depriving learners' opportunities to be actively involved. For example, educators who begin to use new instructional technology, such as graphical calculators and/or computers, may feel lost and unsure about what to do owing to inadequacy of skills (Power \& Thomas, 2007).

\section{Factors Impacting on Learners' Academic Performance}

\subsection{Stress}

Various scholars have documented the relationship between stress and low productivity (Comer, 2013; Coon \& Mitterer, 2010; Kalat, 2011). Stress refers to a pattern of emotional state, cognition and physiological reaction occurring in response to stressors, and it is perceived as potentially harmful, challenging and frustrating as it can impair one's thinking to an extent that they fail to achieve their organizational goals (Miller \& Khoza, 2008). Stress can lead to decreased productivity, apathy, illness, increased absenteeism and poor work quality. In a study undertaken in Limpopo Province among educators, Kruger and Roets (2013) found that $66 \%$ of participants reported to have experienced stress and attributed it to learners' behavioural problems and workload. Majority of educators are exposed to large classes (i.e. massification) and that makes the implementation of inclusive education unbearable and in most cases these educators experience negative attitudes towards learners with barriers to learning (Ladbrook, 2009 \& Mphahlele, 2005).

\subsection{Learners' behavioural problems}

According to Nel (2007), there is also growing evidence that educators fail to master their roles competently because in a study conducted among educators in the Vaal Triangle, Sedibeng district, regarding the support of learners experiencing barriers to learning, $49.9 \%$ of respondents indicated that they were unable to address barriers to learning. Given the findings of her research, Nel (2007) proposed professional development for educators to successfully implement 
inclusivity. Because certain behavioural problems could be the result of learning barriers which are intrinsic in nature, educators cite that parent- support still remains a challenge in South Africa (McKenzie \& Loebenstein, 2007; Nel, Nel \& Lobolane, 2012). A research study also conducted in South Africa, a decade ago, Prinsloo (2001) found that $60 \%$ of educators reported to experience difficulty identifying learners with emotional problems and had no background of inclusive education policy and the professional development workshops are being conducted during awkward times and are relatively short, Nel (2007), in researching about the main factors contributing to incompetence of educators, she found that lack of continuous training gives rise to high failure rate of learners. This author established that a group of educators in Gauteng and Free -State Province were unable to compile assessment forms which are essential for determining learners' progress. In another research study, Nicholas (2008) found that educators developed a negative attitudes toward in-service training because the facilitators had not reached their specific objectives in ensuring that the educators gain as much knowledge and skills to deal with diversity in their classroom. Lumpe et al ., (2012) attribute such inadequacies of educators to the five areas of educator competence which do not address the five areas, namely; content knowledge, pedagogical content knowledge, pedagogical and psychological knowledge, organisational and counselling knowledge.

\subsection{Ineffective communication among educators}

When the principals are unable to influence educators positively, continual problems of low expectation, unfair discipline practices and poor learner performance will be encountered (Madsen \& Mabokela, 2013). In a qualitative research study conducted among school principals in South Africa, to determine causal factors of ineffective management in schools, Msila (2011) found that of the 56 principals participated in the study, majority cited that the democratic policies that are entrenched by Teachers' Unions also contribute to their inefficiency and ineffectiveness to perform their duties without being intimidated. Another hindrance which contributes to ineffective communication is the inability of the principals to prepare the information on time such as memorandum and circulars issued by the district which may have legal implication on the posts of temporary educators (Keil \& McConnahan, 2005). In Nigeria, Nakpodia (2011) investigated the perceptions held by principals and educators regarding communication and human resource management. In a quantitative research study of 389 respondents, made of 335 educators and 54 principals, the findings revealed that principals and educators who were not university graduates lacked in communication and human resource management.

In contrast, Sethosa (2001) found that educators, who come from schools that foster healthy communication with their principals, attend in-service training and often tend to bring innovations on how to teach. They acquire necessary skills and able impart knowledge to their colleagues and learners rather than being dominant during teaching. Because of their involvement in such workshops, they contribute positively, share the strategies that are being employed in their respective schools to improve learning and application of different teaching and methods that enhance cognitive stimulation of learners (Bredeson, 2003).

\subsection{Incompetence of educators and scarcity of resources}

Based on the report by Department of Basic Education, there were only 8696 South African schools (out of 26000 ) in 2012 with ILST, of whom 16672 ILST educators had received training of inclusive education through short courses (Department of Basic Education, 2012). From this staggering proportion of educators who have not received training, Schoeman (2012) found that educators lack relevant skills and appropriate knowledge to practise inclusive pedagogy to support learners who experience barriers to learning. While black South African learners generally perform poorly in Mathematics (Brodie, 2004; Tachie \& Chireshe, 2013) in the Eastern Cape Province, where the matric pass rate continues to decline, Msila (2013) conducted a study among learners from ten secondary schools in Mthatha. A notable finding was that $60 \%$ of learners reported they were taught by unqualified educators. In contrast, Shindler (2008) in her investigation of the factors contributing to pass rate of Matric learners, she found affluent background playing a vital role. In her study, she depicted that learners from provinces such as the Western Cape and Gauteng, perform satisfactorily. The following deductions can be drawn:

- In affluent provinces, educators manage to attend professional development or in-service training since there is on scarcity of transport in comparison to rural areas.

- In rural areas, there are schools that are still without libraries and computers, which could augment incompetent educators.

- Distribution of human resources (e.g educators) per provinces varies.

With regard to health services, by provinces, $88 \%$ of the schools in the Western Cape had access to the services 
of health professionals (i.e. psychologists and social workers) as compared to only $0.5 \%$ of schools in the Eastern Cape (where there is a shortage of qualified educators, resources and infrastructure) and only $3 \%$ in Limpopo (DoBE, 2012).

\subsection{Inadequate training of principals}

Inadequate training of principals in acquisition of skills and positive attitudes which are relevant in diversified school environment (Nakpodia, 2011) coupled with unfair appointment of principals to positions without proper qualifications and relevant experience, contribute to conflicts, ineffective communication and collapse of culture of learning and teaching (COLT). Such inadequacy continues create layers of complexities including ineffective communication amongst staff, administrators and SGB (Moloi \& Bush, 2007). During meetings, communication gets distorted by differences in cultural values, languages and points of view. So it is crucial that the principals get professional development in order to be flexible in their approach to acknowledge beliefs and expereince of educators who have qualifications in Educational Management and Leadership so that negative attitude may not be developed (Arlestig, 2008; Nelson \& Quick, 2005). According to Kalat (2011) attitude may described as a positive or negative feeling toward an object, person or situation, and the attitudes result from a complex interaction of beliefs, feelings and values. Keil and McConnahan (2006) found that a lack of effective communication within the school contributes to low morale and stress by educators, conflicts among educators as a result of negative attitude. In agreement with this finding, Louw and Louw (2007) found that when educators are not in good terms with the principals, lack of team-spirit prevails.

While the appointment of majority of school managers in most black schools in South Africa remains questionable, following the headlines in the City Press newspaper that Teacher's Unions sell the posts at a price which is exorbitant (Harper \& Masondo, 2014), not all principals are under- qualified. Based on the findings brought by Msila (2011) principals who were interviewed regarding the challenges that are being experienced by managers, they expressed that the district officials do not avail themselves and show no interest in their schools and that leave them with no choice but to manage through "trial and error". In addition, the participants cited that lack of support from the district has contributed to the erosion of their self-esteem and self-confidence

\subsection{Overcrowding and HIV/AIDS}

Louw and Louw (2007) are of the opinion that the class size is another aspect of school structure, which must be manageable for academic excellence, particularly for learners in lower grades and those from disadvantaged background. But in South Africa it is still a challenge to have schools which are well resourced and having well-trained and substitute educators. Drawing from the White Paper 6 ( DoE, 2001) such unbalanced ratio of educators to learners and the network support within the schools tend to lead to poor delivery services by educators, and, in turn, contribute towards encountering of intellectual deficits by learners, owing to a lack of cognitive stimulation (Bee \& Boyd, 2003).

Due to a large number of educators infected and affected by HIVIAIDS, very often learners are not being attended to, because of high rate of teacher absenteeism, ill-health and death of their loved ones. Statistically, in 2008, almost 30\% of South African educators were living with HIVIAIDS, and this pandemic was said to be having a highest prevalent among educators in KwaZulu- Natal, Mpumalanga and Eastern Cape (Niemann, 2008). It is therefore imperative that the government should appoint permanent substitute educators to ensure that teaching and learning continues even when others have gone for the workshops (Mosoge, 2008).

\section{Conditions for Successful Professional Development}

To experience effective professional development, Mosoge (2008) posits that the school climate must be affected positively by shared norms, values and sound ethos. Openness, friendliness and trust among educators should prevail in order to achieve the common goal, thus, to improve teaching and learning. Accessibility to adequate materials, resources must be made available so that educators may work in teams, conduct action research, participate in seminars and plan lessons together. The principals should also ensure that the schools are free from conflicts because they can hamper effective professional development from taking place. Unresolved conflicts have the power to destroy teamwork and polarize groups. They can produce irresponsible or regrettable behaviour (e.g. personal attacks between staff members). Though conflicts are inevitable, Donald et al., (2006) suggest that collaboration or constructive problem-solving is essential because it will enable the concerned groups or educators reach the solution amicably without feeling that the principal has favourites. 


\subsection{Characteristics of professional development and teaching styles}

Scheerens (2010) is of the opinion that professionally developed educators must be characterized by professionalism, reasoning, sense of expectancy and leadership. By professionalism, this author stresses that educators must show commitment in everything they do to enable all learners to be successful. Furthermore, they must be consistent, fair and guided by justice. As explained in the preceding section, professionalism should manifest in collaboration, whereby knowledge sharing enable the educators to rely on critical thinking, reflection and self-direction as opposed to teaching and condoning rote learning (learning without insight) (Lessing \& de Witt, 2007).

\subsubsection{Problem- solvers and scaffolding}

According to Scheerens (2010) professionally developed educators must be problem -solvers and transmitters of reasoning skills to their learners. They should drive for excellence and improve teaching and learning through research of new approaches in order for learners to be intellectually curious, and recognise cause and effects. In addition, educators must be flexible, accountable and show passion for learning. They must support the learners unconditionally and create a conducive environment to enable learners to become independent in their learning through innovative approaches. In dealing with learners experiencing barriers to learning, educators should act as scaffolds by bringing the principles of cooperation, critical thinking and social responsibility so that learners may act responsibly and actively in their learning (Swartz, de la Rey, Duncan \& Townsend, 2011). Scaffolding is a process in which educators offer guidance and support in helping a learner to reason, solve a problem, or master a task in such a way that the learner eventually becomes more proficient and capable. To achieve this, educators should create the zone of proximal development (ZPD). The zone of proximal development, according to Vygostsky, refers to the gap between what the learner is already able to do and what she or he is not yet capable of doing (Pastorino \& Doyle- Portillo, 2011). The reason for this is because, according to White Paper 6 issued by the Department of Education (2001) educators are still not adequately trained to identify the needs of their learners (e.g. psycho- social disturbances, developmental impairment, different learning barriers) and these results in their roles being vague. Supporting this is Prinsloo (2001) and Gwala (2006) who found that educators are unable to support the learners with their emotional, intellectual and social welfare because they are diverse in nature and in turn, they impact negatively on their professional development. But Mosoge (2008) is concerned about whether the support that the district provides is sufficient to educators so that they may be confident in facing new challenges and in implementing learnt practices.

\subsubsection{Authoritative teaching style}

The distinction must be noted that the leadership or teaching styles of educators are significant in teaching and learning. For instance, Pastorino and Doyle-Portillo (2011) found that authoritative educators become involved in their learners' emotional and academic lives and are able to display, warmth and affection towards them. Furthermore, they emphasize values, and morals in their learners, resulting in independence, self- actualisation among such learners. As a result, learners guided by educators who are authoritative, tend to take decision and have good command of communication. Various scholars have examined the relationship between self-efficacy of learners and authoritative teaching style. Selfefficacy is the successful execution of required behaviour to produce desired outcomes. Furthermore Muijs, Harris \& Lindsay (2004) assert that activities for professional development must be properly planned and be systematically presented with the aim to enhance personal growth of the educators so that they display positive attitudes to learners with learning barriers. From this perspective, it is proper to infer that the learners' performance may improve because their educators are guided by fundamental principles of professional development, namely; foundation of skills and knowledge by educational personnel, learner participation, provision of feedback and follow-up, and measure changes in learner performance. By presenting themselves as consistent, clear and enthusiastic about their teaching, Gultig and Stielau (2000) mention that they give learners a sense of security because they know the subject- matter as compared to educators who humiliate and scorn the learners.

On the other hand, Louw and Louw (2007) mention that uninvolved educators are those that show minimum interaction and affection towards their learners as compared to authoritative educators. They are unaware of the learners' needs and become uninvolved to the point of being neglectful. As a result, such learners may display impulsive behaviour, lack of self- regulation and self-esteem. For example, in a South African study undertaken by Holborn and Eddy (2011) it was found that learners displayed factors associated with poor educational performance, anti-social behavior and delinquency in their lives. In addition, Holborn and Eddy postulated that girls may struggle in their academic 
performance, self -confidence, and adjustment in behavior control because the educators are not supportive. Louw and Louw (2007) is concerned that once learners are unable to cope academically, they may drop out of school prematurely and likely to be the victims of sexual molestation or abuse and HIVIAIDS. Authoritarian teaching style refers to the type of an educator who shapes, controls and evaluates the behaviour and attitudes of children according to a set of standards. Furthermore, authoritarian educators have a high level of demandingness, punitive, forceful and believe that a child should be obedient. They preserve the order of a bureaucratic structure by limiting learners' autonomy. Authoritarian parents are too strict, demanding and threaten their children with severe punishment when they disobey rules. In a study conducted by found that large percentage of juvenile delinquents used to come from schools where educators were not professionally developed to provide loco- parental love and care (Louw \& Louw, 2007).

\section{Conclusion}

In line with the policy of inclusion, educators have to display their expertise and experience to adapt to the new model of teaching in order to accommodate learners with special needs (Pillay \& Di Terlizzi, 2009). The only way to achieve this is through retraining of educators in order to adapt to the changes brought by government. Therefore, educators need to be work- shopped in programmes that will enhance their competence and stimulate a richer learning environment (Early \& Bubb, 2004; Weeks, 2000). Finally, in the changes of school design, culture and structures, experienced educators who are capable of making an impact on the organisation should be acknowledged by the school management team (SMT) to restore the culture of teaching and learning.

\section{Bibliography}

Arlestig, H. (2008). Communication between principals and teachers in successful school.[PhD thesis].Sweden: Urmea Universitet. Bee, D. \& Boyd, D. (2003). Life-span development. Study edition. (3rd edition). Boston: Allyn and Bacon.

Bredeson, P.V. (2003). Designs for learning. Thousand Oaks, CA: SAGE.

Brodie, K. (2004). Rethinking teachers' mathematical knowledge: A focus on thinking practice. Perspective in Education, 22(1): 65-80.

Clarke, A. (2007). The Handbook of School Management. Cape Town: Kate Mc Callum.

Comer, R.J. (2009). Abnormal Psychology.(8th Edition). Worth Publishers: New York.

Coon , D., \& Mitterer, J.O. (2010). Introduction to Psychology. Gateways to mind and behaviour. (12 thed.). Belmont: Wadsworth Cengage Learning.

Department of Education. (2001). Education White Paper 6. Special Needs Education: building an inclusive education and training system. Pretoria: Government Printers.

Department of Basic Education. 2012. "Progress Report on the Implementation of Education White Paper 6: 2001-2012." Presented to the Parliamentary Portfolio Committee on Women, Children and Persons With Disability.

Donald, D., Lazarus, S., \& Lolwana, P. (2006). Educational Psychology in Social Context. (3rd Edition). Oxford University Press: Cape Town.

Gultig, J. \& Stielau, J. (2002).Getting Practical About Outcomes-based Teaching. Learning - Guide. Cape- Town: Oxford University Press.

Gwala, Q.V. (2006). Challenges facing the implementation of inclusive education in primary schools. [MEd dissertation]. Pitermaritzburg: University of KwaZulu- Natal.

Harper, P., \& Masondo, S. (2014). How Sadtu sells its posts. (27 April, 2014, City Press).

Harwell, S.H. (2003). Teacher Professional Development: It's Not a n Event, It's a Process. Texas : CORD.

Holborn, L. \& Eddy, G. (2011). First Steps to healing the South African Family. A research paper by the South African Institute of Race Relations, Johannesburg.

Huberman, M. (1996). Moving mainstream: Taking a closer look at teacher research. Language Arts, 73(2), 124-140.

Joyce, B., \& Showers, B.(2003). Student achievement through staff development. Alexandria, Virginia: Association for Supervision and Curriculum Development.

Kalat, J.W. (2011). Introduction to Psychology. (9th ed.). Australia: Cengage Learning

Keil,V.L., \& McConnahan, W.R. (2005). Meaningful written communication by administrators. Connections, Vol 7. 20-26

Kruger, E., \& Roets, H. E. (2013). Guidelines for the management of job related stress amongst secondary school teachers in the Limpopo Province. Online Journal of Education Research, 2(3), 41-49.

Ladbrook, M.W. (2009). Challenges experienced by educators in the implementation of inclusive education in primary schools in South Africa. [MEd Dissertation]. Pretoria: University of South Africa

Lessing, A., \& de Witt, M. (2007). The value of continuous professional development: South African Journal of Education, Vol 27(1), 5367

Louw, D. \& Louw, A. (2007). Child and adolescent development. Bloemfontein: University of Free State.

Lumpe, A. , Czerniak, C. , Haney, J ., \& Beltyukova, S.(2012). Beliefs about Teaching Science: The relationship between elementary, teachers' participation in professional development and student achievement. International Journal of Science Eaducation. 
Vol. 34, No. 2. 153-166

Madsen, J., \& Mabokela, R. (2013). Leadership Challenges in Addressing Changing Demographics in Schools. NASSP Bulletin, 0192636513514110

McKenzie, J. A., \& H. Loebenstein. 2007. "Increasing Parent Recognition and Involvement." In Responding to the Challenges of Inclusive Education in Southern Africa, P. Engelbrecht \& L. Green (Eds ), 186-202. Pretoria: Van Schaik.

Miller, K., \& Khoza, H. (2008). A comparison of teacher stress and school climate across schools with different matric success rates. South African Journal of Education, 28: 221-239.

Moloi, K., \& Bush, T. (2007). An overview of Education Management in South Africa. Management in Education. 20(5):15-22.

Mosoge, J. (2008). Talent development. In: J. Heystek, R. Niemann, J. van Rooyen, J. Mosoge ., \& K.Bipath (Eds.). People in Education. Sandton: Heinemann Publishers, pp 160-193

Mphahlele, M.L. (2005). Support offered by School- Based Support Teams: Experiences of Foundation Phase teachers in Tshwane North. [MEd mini-dissertation]. Pretoria: University of South Africa.

Msila, V. (2011). School Management and the struggle for effective schools. Africa Education Review, Vol 8 (3: 434-449.

Msila, V. (2013). Teacher Unionism and School Management A Study of (Eastern Cape) Schools in South Africa. Educational Management Administration \& Leadership, 1741143213499265.

Muijs, D., Day, D., Harris, A., \& Lindsay, G. (2004). Evaluating CPD: an overview. In: Day B \& Sachs, J. (eds). International handbook on the continuing professional Development of teachers. Berkshire: McGraw-Hill Education.

Mullen, C.A. (2000). Constructing co- mentoring partnerships: walkways we must travel. Theory into Practice, Vol 39(1), 4-11

Nakpodia, E.D. (2011). Principals and teachers' perceptions of communication and human resources management and their compliance with culture in Nigerian educational system. Journal of Language and Culture. Vol 2(5), 82-90.

Nel, M. (2007). A language enrichment programmes for South African Grade 4 ESL learners with limited English Proficiency. A paper presented at the AARE Annual Conference, Fremantle, Perth, Australia.

Nel, N., Nel, M., \& Leboloane, O. 2012. "Assessment and Learner Support." In Learner Support in a Diverse Classroom, edited by N. Nel, M. Nel, and A. Hugo, 47-76. Pretoria: Van Schaik.

Nelson, D. L., \& Quick, J.C. (2005). Organizational behaviour: Foundations, realities and challenges. (4th ed.). Mason: South -Western.

Nicholas, L. (2008). Introduction to Psychology. (2nd edition). Cape Town: UCT Press.

Niemann, R. (2008). Contemporary South African people leadership issues and development. In: J. Heystek, R. Niemann, J. van Rooyen, J. Mosoge., \& K.Bipath (Eds.). People in Education. Sandton: Heinemann Publishers, pp 21-54.

Pastorino, E., \& Doyle- Portillo, A. (2011). What is Psychology? (2nd edition.). Wadsworth. Cengage Learning: Australia

Pillay, J., \& Di Terlizzi, M. (2009). A case - study of a learner's transition from mainstream with special needs (LSEN): Lessons for mainstream education. South African Journal of Education, 29: 105- 126.

Prinsloo, E. (2001). Working towards Inclusive education in South African classrooms. South African Journal of Education. Vol 21(4), 344- 348.

Rebore, R.W. (2014).The Ethics of Educational Leadership. (2nd Edition.). Allyn \& Bacon: Boston.

Richter, D., Kunter, M., Klusmann,U., Lüdtke, O., \& Baumert. J. (2011). Professional development across the teaching career: Teachers' uptake of formal and informal learning opportunities. Teaching and Teacher Education ,27, 116-126.

Scheerens, J. (2010). Teachers' Professional development. An analysis of teachers' professional development based on the OECD's Teaching and Learning International Saurvey (Talis). Belgium: European Union

Schoeman, M. (2012). "Developing an Inclusive Education System: Changing Teachers' Attitudes and Practices Through Critical Professional Development." Paper presented at the National Teacher Development Conference at the University of Pretoria, September 17-19.

Sethosa, M.F. (2001). Assisting teachers to support mildly intellectually disabled learners in the foundation phase in accordance with the policy of inclusion. DEd thesis. Pretoria: University of South Africa..

Shindler, J. (2008). Public schooling. HUMAN RESOURCES DEVELOPMENT REVIEW 2008, 228.

Swartz, L., de la Rey, C., Duncan, N., \& Townsend, L. (2011). Psychology: an introduction. (3rd ed.). Oxford University Press: Cape Town.

Tachie, S. A., \& Chireshe, R. (2013). High Failure Rate in Mathematics Examinations in Rural Senior Secondary Schools in Mthatha District, Eastern Cape: Learners' Attributions.

Weeks, F.H. (2000). Behaviour problems in the classroom: a model for teachers to assist learners with unmet emotional needs. (DEd thesis). Pretoria: University of South Africa. 